\title{
Effect of fatty Amazon fish consumption on lipid metabolism
}

\author{
Efeito do consumo de peixes amazônicos \\ gordurosos sobre o metabolismo lipídico
}

Francisca das Chagas do Amaral SOUZA ${ }^{1}$

Nadja Pinto GARCIA ${ }^{2}$

Rejane Souza de Aquino SALES²

Jaime Paiva Lopes AGUIAR ${ }^{1}$

Wallice Luiz Paxiúba DUNCAN ${ }^{3}$

Rosany Piccolotto CARVALHO²

\section{A B S T R A C T}

\section{Objective}

The present study aimed to evaluate the effect of feeding diets enriched with fatty fish from the Amazon basin on lipid metabolism.

\section{Methods}

Male Wistar rats were divided into four groups: control group treated with commercial chow; Mapará group was fed diet enriched with Hypophthalmus edentatus; Matrinxã group was fed diet enriched with Brycon spp.; and, Tambaqui group was fed diet enriched with Colossoma macropomum. Rats with approximately $240 \mathrm{~g} \pm 0.60$ of body weight were fed ad libitum for 30 days, and then were sacrificed for collection of whole blood and tissues.

\section{Results}

The groups treated with enriched diets showed a significant reduction in body mass and lipogenesis in the epididymal and retroperitoneal adipose tissues and carcass when compared with the control group. However, lipogenesis in the liver showed an increase in Matrinxã group compared with the others groups. The levels of serum triglycerides in the treated groups with Amazonian fish were significantly lower than those of the control group. Moreover, total cholesterol concentration only decreased in the group Matrinxã. High Density Lipoprotein cholesterol levels increased significantly in the Mapará and Tambaqui compared with control group and Matrinxã group. The insulin and leptin levels increased significantly in all treatment groups.

\footnotetext{
1 Instituto Nacional de Pesquisas da Amazônia, Coordenação Sociedade Ambiente e Saúde, Laboratório de Alimentos e Nutrição. Av. André Araújo, 2936, Aleixo, 69060-001, Manaus, AM, Brasil. Correspondência para/Correspondence to: FCA SOUZA. E-mail: <francisca.souza@inpa.gov.br>.

2 Universidade Federal do Amazonas, Instituto de Ciências Biológicas, Departamento de Fisiologia. Manaus, AM, Brasil.

${ }^{3}$ Universidade Federal do Amazonas, Instituto de Ciências Biológicas, Departamento de Morfologia. Manaus, AM, Brasil.
} 


\section{Conclusion}

This study demonstrated that diets enriched with fatty fish from the Amazon basin changed the lipid metabolism by reducing serum triglycerides and increasing high density lipoprotein-cholesterol in rats fed with diets enriched with Mapará, Matrinxã, and Tambaqui.

Indexing terms: Amazon fishes. Diet. Lipid metabolism. Rats, wistar.

\section{R E S U M O}

\section{Objetivo}

Este trabalho avaliou o efeito da alimentação com dietas enriquecidas com peixes gordurosos da região amazônica sobre o metabolismo lipídico.

\section{Métodos}

Ratos machos da linhagem Wistar foram separados em quatro grupos: grupo controle tratados com ração comercial; grupo Mapará, dieta enriquecida com Hypophthalmus edentatus; grupo Matrinxã dieta enriquecida com Brycon spp.; grupo Tambaqui, dieta enriquecida com Colossoma macropomum. Animais com aproximadamente $240 \mathrm{~g} \pm 0,60$ de massa corporal foram alimentados ad libitum por 30 dias e eutanasiados para coleta do sangue total e tecidos.

\section{Resultados}

Os grupos tratados com dietas enriquecidas apresentaram uma redução significativa na massa corporal e da taxa de lipogênese nos tecidos adiposos epididimal, retroperitoneal e carcaça quando comparados ao grupo controle. No entanto, a taxa de lipogênese do fígado aumentou significativamente no grupo Mapará quando comparados aos demais grupos. A concentração sérica de trigilcerideos dos grupos tratados com os peixes amazônicos foi significativamente menor em relação ao grupo-controle. Por outro lado, o colesterol total redu-ziu significativamente apenas no grupo Mapará. Os níveis de lipoproteína de alta densidade aumentaram de forma significativa nas rações preparadas com Mapará e Tambaqui. Os niveis de insulina e leptina apresentaram aumento significativo em todos os tratamentos em relação ao grupo controle.

\section{Conclusão}

Este estudo demonstrou que o enriquecimento das dietas com peixes amazônicos gordurosos alterou o metabolismo lipídico em ratos diminuindo a concentração plasmática de triglicerídeos e, concomitantemente, elevando os teores de lipoproteína de alta densidade nos grupos alimentados com dietas enriquecidas com as espécies Mapará, Matrinxã e Tambaqui.

Termos de indexação: Peixes amazônicos. Dietas. Metabolismo dos lipídeos. Ratos wistar.

\section{INTRODUCTION}

Obesity is considered a global public health problem in developed and developing countries?. Obesity pathophysiology involves complex neuroendocrine and metabolic mechanisms ${ }^{2}$. The main processes involved in cardiac diseases are atheroma, thrombogenic, and dietary, and factors that affect lifestyle. High intake of saturated fats, cholesterol, and calories lead to obesity, and therefore, are factors that affect lipid metabolism³. The quantity and nature of the fat ingested daily influence the concentration of plasma cholesterol. High cholesterol levels in the blood are related to the incidence of atherosclerotic vascular diseases, especially coronary diseases ${ }^{4}$. On the other hand, high density lipid cholesterol plays an important role in maintaining the plasma cholesterol levels within a compatible range, since it removes free cholesterol from plasma ${ }^{5}$. The main function of High Density Lipoprotein (HDL) is to build temporary reserves for total lipids, cholesterol, and apoproteins, protecting against atherosclerosis ${ }^{6}$. Estadella et al. ${ }^{7}$, showed that a high-fat or mixed diet promotes a smaller rate of lipogenesis in retroperitoneal adipose and epididymal rat tissues. The accumulation of fat in the tissues and insulin resistance has been associated with dyslipidemia, 
higher plasma total cholesterol level, Low Density Lipoprotein-cholesterol (LDL-c), Very Low Density Lipoprotein-cholesterol (VLDL-c), triglycerides; and lower HDL-C.

The ability of some foods to reduce cholesterol levels has been investigated in the last decades. Fish lipids are among these components. Since the 1970s, studies have confirmed the role of omega-3 fatty acids, especially Eicosapentaenoic Acid (EPA), in controlling cholesterol and its fractions, and consequently, in preventing cardiovascular diseases ${ }^{8}$. Researchers have found that the daily intake of omega-3 fatty acids can reduce the levels of triglycerides from $25 \%$ to $30 \%{ }^{9}$. Xin et al. ${ }^{10}$ state that short-term fish oil supplementation can have a favorable influence on the frequency domain of the heart rate variability.

The nature and amount of dietary lipids protect against and/or promote cardiovascular problems, and considering the high seafood intake in the Brazilian North region, this study aimed to examine whether diets containing fatty fish from the Amazon region, such as: mapará (Hypophthalmus edentatus), matrinxã (Brycon spp.), and tambaqui (Colossomoa macropomum) affect lipid metabolism in Wistar rats.

\section{METHOD S}

\section{Animals}

Forty adult male Wistar (Rattus norvegicus) rats weighing approximately $240 \pm 0.60$ grams, from the animal facility of the Universidade Federal do Amazonas (UFAM) were divided into four groups according to diet: Control Group (CG), Mapará Group (GMAP), Matrinxâ Group (GMAT), and Tambaqui Group (GTAB). All animals were kept in individual cages under a temperature of $24^{\circ} \mathrm{C}$ to $28^{\circ} \mathrm{C}$ and $12 / 12$-hour light-dark cycle. The animals had free access to food and water. The experimental period lasted 30 days. The study was approved by the Animal Ethics Committee of the UFAM under Protocol 00014/12.

\section{Preparation of the diets}

The fish were transported to the Coordenação de Pesquisas em Tecnologia do Alimento/ Instituto Nascional de Pesquisas da Amazônia (CPTA-INPA) where they were filleted and submitted to mechanical muscle separation in a German Baader model 694 separator. The resultant meat was distributed in rectangular metal trays and frozen to $-30^{\circ} \mathrm{C}$. The frozen blocks weighting roughly $7 \mathrm{~kg}$ and having a width of $5 \mathrm{~cm}$ each were cut with an electric band saw in portions of roughly $500 \mathrm{~g}$ and wrapped in polyethylene film. The frozen blocks were placed in isothermal boxes containing ice, transported to the Physiology Laboratory of UFAM and stored at $-18 \pm 1^{\circ} \mathrm{C}$. The Amazon fish-based diet consisted of Labina chow $(72.5 \%)$, casein $(12.5 \%)$, and mechanically separated meat of each species (15.0\%). All components were ground and mixed. The final composition of each chow was approximately $22.0 \%$ proteins, $10.5 \%$ fats, $40.0 \%$ carbohydrates, and $16.0 \%$ fibers (Table 1). The caloric density determined by an adiabatic calorimeter (IKA-C400) was approximately $251.40 \mathrm{~kJ} / \mathrm{g} \pm 0.30 \mathrm{~kJ} / \mathrm{g}$ (35.0\% calories as fats) for each palatable high-fat diet, and $17.03 \mathrm{~kJ} / \mathrm{g}$ for the standard diet.

\section{Experimental Procedure}

\section{Body weight and food intake}

The rats' food intake and body mass were assessed daily for 30 days. Energy intake was determined by multiplying food intake by energy density. At the end of 30 days, the forty rats were sacrificed by decapitation and the total blood extracted. Next, this material was centrifuged at 7500rpm for 2 minutes in an Eppendorf Model 5415 centrifuge. After one hour, an intraperitoneal injection of $3 \mathrm{mCi}{ }^{3} \mathrm{H}_{2} \mathrm{O}$ in a volume of $0.3 \mathrm{~mL}$ was given for determining the rate of lipogenesis in vivo. Total blood was collected. The carcass and the tissues liver, Retroperitoneal Adipose (RET), 
and Epididymal (EPI) were immediately weighed. In vivo lipogenesis was determined by the incorporation of ${ }^{3} \mathrm{H}_{2} \mathrm{O}$ in saponified lipids according to the Robinson and Williamson method $^{11}$. The tissue samples were digested in $3.0 \mathrm{~mL}$ of $30 \% \mathrm{KOH}$ and $3.0 \mathrm{~mL}$ of ethanol during $2 \mathrm{~h}$ at $70^{\circ} \mathrm{C}$. After cooling, $2.0 \mathrm{~mL}$ of $\mathrm{H}_{2} \mathrm{SO}_{4} 12 \mathrm{~N}$ was added and the lipids were extracted with $10.0 \mathrm{~mL}$ of ether in petroleum ${ }^{12}$. This extract was washed with $2.0 \mathrm{~mL}$ of distilled water and evaporated until dry. The radioactivity of $20 \mu \mathrm{L}$ of the serum in the samples was used to determine specific activity. The rate of lipogenesis was calculated as micromoles ${ }^{3} \mathrm{H}_{2} \mathrm{O}$ of lipids incorporated by gram by hour. The lipid content of the tissue was determined by the gravimetric method $^{13}$. The glycogen ${ }^{14}$ content of the liver was determined by the anthrone method $-\mathrm{H}_{2} \mathrm{SO}_{4}$. Plasma was obtained by centrifugation and aliquots were used for measuring glucose, triglycerides, total lipids, cholesterol, high-density lipoprotein, insulin, and leptin. For these measurements, Doles (Brazil) kits were used. The concentration of insulin (Coat-A- Count DPC MedLab, CA, USA) and leptin (Linco Research, INC, MO, USA) were determined by radioimmunoassay kits.

\section{Statistical analysis}

The statistical tests were one-way Analysis of Variance (Anova) followed by the Tukey test. The differences were considered significant when $p<0.05$.

\section{RES U L T S}

\section{Diet composition}

The percent macronutrient composition and fatty acids of the total lipid content of the CG, GMAP, GMAT, and GTAB diets are shown in Table 1; we see that the total protein content did not differ significantly between the groups. The percentage of carbohydrates in the CG group was statistically smaller than that of the groups fed Amazon fish, except for the group GMAP. Regarding fibers present in the percent composition of the diets, the CG had the lowest percentage. The GMAP group had higher fiber percentage than the groups GMAT and GTAB. The GMAP group had a higher lipid percentage than groups $C G$, GMAT, and GTAB. The CG fatty acids have a higher percentage of linolenic and linoleic acids. The GMAP was the only group with Docosahexaenoic (DHA) and EPA.

Table 1. Percent macronutrients (\%) and total fatty acids in the Control (C) diet, diet enriched with ground Mapará (MAP), ground Matrinxã (MAT), and ground Tambaqui (TAB). Manaus (AM), Brazil, 2012.

\begin{tabular}{|c|c|c|c|c|}
\hline Macronutrients & GC & GMAP & GMAT & GMAP \\
\hline Proteins & $22.4^{\mathrm{a}}$ & $22.3^{\mathrm{a}}$ & $22.6^{\mathrm{a}}$ & $23.7^{\mathrm{a}}$ \\
\hline Carbohydrates & $39.1^{\mathrm{a}}$ & $38.2^{\mathrm{a}}$ & $41.3^{c}$ & $40.3^{d}$ \\
\hline Fibers & $11.4^{\mathrm{a}}$ & $16.7^{b}$ & $15.0^{c}$ & $16.0^{d}$ \\
\hline Lipids & $4.8^{\mathrm{a}}$ & $11.8^{b}$ & $10.0^{c}$ & $9.9^{c}$ \\
\hline Palmitic (16:9) & $20.4^{\mathrm{a}}$ & $23.93^{b}$ & $24.58^{c}$ & $24.8^{c}$ \\
\hline Oleic (18:1n-9) & $27.4^{\mathrm{a}}$ & $24.55^{b}$ & $27.9^{a}$ & $38.85^{d}$ \\
\hline Stearic (18:0) & $5.12^{\mathrm{a}}$ & $7.65^{b}$ & $6.93^{a}$ & $9.84^{c}$ \\
\hline Palmitoleic (16:1n-7) & - & $3.56^{\mathrm{b}}$ & $7.5^{c}$ & $1.72^{\mathrm{d}}$ \\
\hline Linolenic (18:3n-3) & $9.91^{\mathrm{a}}$ & $3.76^{b}$ & $2.35^{c}$ & $2.66^{c}$ \\
\hline Linoleic (18:2n-6) & $41.0^{a}$ & $11.11^{b}$ & $18.52^{c}$ & $18.62^{c}$ \\
\hline Myristic (14:0) & $2.07^{a}$ & $0.56^{b}$ & $2.46^{a}$ & $0.66^{b}$ \\
\hline Docosahexaenoic (22:6n-3) & - & 2.9 & - & - \\
\hline Eicosapentaenoic (20:5n-3) & - & 2.4 & - & - \\
\hline
\end{tabular}

Note: The values are expressed as means \pm standard error mean. Values followed by the same letter do not differ according to the Tukey test $(p<0.05)$. 


\section{Weight gain, energy value, metabolic efficiency, and fat content}

Table 2 shows that the fat content of the carcass in the groups fed diets with 15\% meat was smaller than that of the control. However, the fat content of the carcass of groups GMAT and GTAB did not differ from each other, but both were higher than GMAP. The measure of the masses of the adipose epididymal and retroperitoneal tissues and liver of the GMAT, GMAP, and GTAB groups were greater than those of the control group. The CG consumed less energy than the other groups. On the other hand, the GMAP group had greater total energy intake than the GTAB and GMAT. GTAB total energy intake was significantly higher than that of GMAT. The control group gained more weight than the groups GTAB and GMAP. The metabolic efficiency of the control group was lower than that of the other groups.
On the other hand, the GTAB group had a metabolic efficiency greater than the GMAP and GMAT groups. The GMAT had a lower metabolic efficiency than the group GMAP.

\section{Lipogenesis}

In the CG's, GMAP's, and GTAB's livers, the rate of lipogenesis was similar (Table 3). However, the GMAT group had a higher rate of liver lipogenesis than the GMAP, GTAB, and CG groups. The lipogenesis rates of the GMAP, GMAT, and GTAB were lower than those of the $C G$ group. The animals in the GMAP, GMAT, and GTAB groups had lower RET and EPI adipose tissue lipogenesis than the CG. However, the lipogenesis rate of the EPI adipose tissue of the GMAT group was higher than that of the groups GTAB and GMAP.

Table 2. Body weight gain ( $\mathrm{f}$ ), total energy intake ( $\mathrm{kJ})$, metabolic efficiency ( $\mathrm{JJ} / \mathrm{g}$ of body weight gain), fat content of the carcass (g/100g), Retroperitoneal (RET) adipose tissue mass, Epididymal (EPI) adipose tissue mass, and liver mass of rats fed control diet and diets enriched with Ground Mapará (GMAP); Ground Matrinxã (GMAT) or Ground Tambaqui (GTAB). Manaus (AM), Brazil, 2012.

\begin{tabular}{|c|c|c|c|c|c|c|c|c|}
\hline \multirow{2}{*}{ Variables } & \multicolumn{2}{|c|}{ CG } & \multicolumn{2}{|c|}{ GMAP } & \multicolumn{2}{|c|}{ GMAT } & \multicolumn{2}{|c|}{ GTAB } \\
\hline & M & SD & M & SD & M & SD & M & SD \\
\hline Body weight gain & 80.30 & $6.78^{\mathrm{a}}$ & $66.98^{b}$ & $3.34^{\mathrm{b}}$ & 70.08 & $5.24^{c}$ & 56.75 & $5.26^{\mathrm{d}}$ \\
\hline Total energy intake & 6840.4 & $153.9^{\mathrm{a}}$ & 7910.6 & $183.2^{\mathbf{b}}$ & 7284.3 & $183.3^{c}$ & 7441.1 & $188.5^{d}$ \\
\hline Metabolic efficiency & 96.44 & $7.07^{a}$ & 119.72 & $4.43^{b}$ & 107.44 & $6.47^{c}$ & 144.17 & $14.52^{d}$ \\
\hline Fat content of the carcass & 8.2 & $0.025^{a}$ & 3.78 & $1.56^{c}$ & 5.53 & $5.00^{\mathbf{b}}$ & 4.01 & $0.89^{b}$ \\
\hline EPI mass & 0.86 & $0.025^{\mathrm{a}}$ & 1.04 & $0.0006^{\mathbf{b}}$ & 1.04 & $0.0006^{b}$ & 1.02 & $0.008^{b}$ \\
\hline RET mass & 0.65 & $0.06^{a}$ & $1.05^{\mathbf{b}}$ & $0.007^{b}$ & 1.05 & $0.006^{b}$ & 0.99 & $0.027^{b}$ \\
\hline Liver mass & 9.08 & $0.300^{\mathrm{a}}$ & 11.59 & $0.007^{b}$ & 11.66 & $0.442^{b}$ & 11.05 & $0.250^{b}$ \\
\hline
\end{tabular}

Note: The values are expressed as means \pm standard error mean. Values followed by the same letter do not differ according to the Tukey test $(p<0.05)$.

Table 3. In vivo lipogenesis rate ( $\mu \mathrm{mol}{ }^{3} \mathrm{H}_{2} \mathrm{O}$ incorporated in lipids/g of tissues.h) in the Epididymal (EPI) and Retroperitoneal (RET) adipose tissues, liver, and carcass of the rats fed a control diet and diets enriched with Ground Mapará (GMAP); Ground Matrinxã (GMAT) or Ground Tambaqui (GTAB). Manaus (AM), Brazil, 2012.

\begin{tabular}{|c|c|c|c|c|c|c|c|c|}
\hline \multirow{2}{*}{ Tissues } & \multicolumn{2}{|c|}{$C G$} & \multicolumn{2}{|c|}{ GMAP } & \multicolumn{2}{|c|}{ GMAT } & \multicolumn{2}{|c|}{ GTAB } \\
\hline & $M$ & SD & $M$ & SD & $M$ & SD & $M$ & SD \\
\hline EPI & 34.46 & $39.88^{a}$ & 3.42 & $0.79^{b}$ & 4.6 & $2.04^{c}$ & 3.28 & $0.82^{b}$ \\
\hline RET & 12.92 & $9.9^{a}$ & 3.73 & $1.47^{\mathbf{b}}$ & 3.64 & $0.84^{\mathbf{b}}$ & 3.76 & $1.41^{\mathrm{b}}$ \\
\hline Liver & 8.24 & $2.22^{\mathrm{a}}$ & 7.63 & $2.64^{\mathrm{a}}$ & 15.52 & $8.82^{b}$ & 9.40 & $2.08^{a}$ \\
\hline Carcass & 7.71 & $4.83^{a}$ & 1.30 & $0.43^{b}$ & 1.42 & $0.55^{b}$ & 1.67 & $0.32^{b}$ \\
\hline
\end{tabular}

Note: The values are expressed as means \pm standard error mean. Values followed by the same letter do not differ according to the Tukey test $(p<0.05)$. 
Table 4. Serum levels of glucose, Triglycerides (TG), total lipids, total cholesterol, LDL-C, VLDL-C, HDL-c, total proteins expressed as (mg/ $\mathrm{dL}$ ) and leptin $(\mathrm{ng} / \mathrm{mL}$ ) of rats fed a control diet and diets enriched with Ground Mapará (GMAP); Ground Matrinxã (GMAT) or Ground Tambaqui (GTAB). Manaus (AM), Brazil, 2012.

\begin{tabular}{|c|c|c|c|c|c|c|c|c|}
\hline \multirow{2}{*}{ Tissues } & \multicolumn{2}{|c|}{$C G$} & \multicolumn{2}{|c|}{ GMAP } & \multicolumn{2}{|c|}{ GMAT } & \multicolumn{2}{|c|}{ GTAB } \\
\hline & $M$ & SD & M & SD & M & SD & $M$ & SD \\
\hline Glucose & 139.87 & $8.87^{\mathrm{a}}$ & 154.28 & $7.60^{\mathrm{b}}$ & 134.24 & $4.20^{\mathrm{ac}}$ & 117.34 & $4.18^{\mathrm{d}}$ \\
\hline TG & 60.43 & $4.08^{\mathrm{a}}$ & 40.55 & $3.62^{b}$ & 44.62 & $4.98^{b}$ & 38.96 & $4.49^{b}$ \\
\hline Total cholesterol & 76.28 & $4.44^{\mathrm{a}}$ & 67.33 & $5.84^{\mathrm{a}}$ & 59.39 & $3.80^{\mathrm{a}}$ & 65.68 & $4.33^{\circ}$ \\
\hline HDL-C & 8.79 & $0.81^{a}$ & 13.67 & $1.11^{\mathrm{b}}$ & 7.08 & $0.96^{\mathrm{a}}$ & 11.44 & $1.38^{b}$ \\
\hline Total proteins & 4.68 & $0.42^{\mathrm{a}}$ & 4.81 & $0.43^{a}$ & 4.29 & $0.14^{\mathrm{a}}$ & 4.23 & $0.17^{\mathrm{a}}$ \\
\hline Leptin & 1.63 & $0.26^{\mathrm{a}}$ & 4.38 & $0.65^{a b}$ & 3.90 & $0.42^{\mathrm{ac}}$ & 6.34 & $1.70^{\circ}$ \\
\hline Insulin & 11.75 & $1.32^{\mathrm{a}}$ & 14.14 & $2.56^{\mathrm{a}}$ & 14.12 & $2.01^{\mathrm{a}}$ & 11.30 & $1.07^{\mathrm{a}}$ \\
\hline
\end{tabular}

Note: The values are expressed as means \pm standard error mean. Values followed by the same letter do not differ according to the Tukey test $(p<0.05)$

TG: Triglyceride; HDL-c: High Density; Lipopropein-cholesterol; M: Mean; SD: Stardand Deviation.

\section{Plasma metabolites}

Table 4 shows that the total cholesterol and total protein contents did not change in the groups treated with the enriched diets with respect to the Control group. The groups GMAP, GMAT, and GTAB presented a significant reduction in plasma Triglyceride (TG) levels compared with the Control group. The groups GMAP and GTAB presented a significant increase in HDL-c when compared with the control and GMAT groups. Additionally, the plasma glucose of group GTAB decreased significantly when compared with the groups GMAT, GMAP, and CG. The increase in the glucose levels of the group GMAP was greater than that of the other groups. However, plasma insulin did not change significantly in any of the groups. Leptin in the CG was significantly lower than in the treated groups (Table 4).

\section{I S C U S S I O N}

In the literature the effect of high-fat diet on body weight is very controversial ${ }^{15,16}$, especially of rats fed diets high in saturated fats and omega6 polyunsaturated fats ${ }^{17}$. The degree of satiety promoted by high-fat diet depends on their physical and chemical properties (chain length, saturation, and conjugation), its carbohydrates, and its palatability ${ }^{18}$. These factors may influence the release of inhibitory gastrointestinal peptides such as cholecystokinin, enterostatin, and apoprotein A-IV ${ }^{19,20}$ and also the digestion, absorption, and metabolic rates. Himaya et al. ${ }^{21}$ reported that the time of satiety in high-fat diets is longer in diets high in carbohydrates because of the higher levels of plasma metabolite substrates such as glucose, TG, and fatty acids. These results may partly explain the fact that Wistar rats present lower intake of diets enriched with mapará (Hypophthalmus edentatus), the fish with the highest lipid content. On the other hand, the rats fed matrinxã (Brycon spp.) consumed as much food as the controls.

Other studies have reported that rats kept with diets enriched with polyunsaturated and saturated fish oil did not vary their food intake ${ }^{22}$. Interestingly, in past decades, this dietary practice of feeding high-fat diet was used as strategy to control obesity, but with little success, since in general this type of diet has high energy content leading to body weight gain ${ }^{21}$. This is in agreement with the group that was fed the diet enriched with matrinxã, which gained more weight than the other groups. The intake of each macronutrient seems to be under strict control to maintain oxidation and the balance status. In case of fats, 
the adjustment is much less precise and higher intake does not stimulate proportional oxidation. The oxidation rate of fatty acids may also be another factor that controls food intake ${ }^{23}$. The accumulation of fats in tissues and the presence of insulin resistance has been associated with dyslipidemias, increase in the plasma level of total cholesterol, LDL-C, VLDL-C, IDL-C, TG, and low HDL-c. Hence, many studies have reported that obesity, dyslipidemia, diabetes type II, high blood pressure, and cardiovascular diseases lead to interrelated metabolic changes known as plurimetabolic syndrome ${ }^{24}$. Nieves et al. ${ }^{25}$ indicate that the lipoprotein profile present seem to result primarily from the increase in central fat probably due to the development of insulin resistance. The reduction of abdominal fat by medication or lifestyle changes or dietary changes or more physical activity could contribute to improve the lipid profile, and avoid the development of atherosclerosis. Suprijana et al. ${ }^{26}$ found a reduction in the levels of TG, total cholesterol, and lipoprotein fractions in rats fed diets enriched with fish oil, which was later observed also by Kim et al. ${ }^{27}$.

Similarly, the results observed in this study show that the intake of fatty Amazon fish reduced TG and cholesterol levels. The effects caused by high-fat diets on the metabolism of animals may be influenced by the type of lipids ${ }^{28}$, gender, and treatment period ${ }^{17,23}$. Patients treated with fish oil rich in omega- 6 fatty acids have experienced lower total cholesterol, LDL-C, TG, and VLDL ${ }^{29}$, and higher HDL-C ${ }^{29,30}$. Similarly, the total cholesterol and TG of the rats fed diets enriched with Amazon fish decreased and the HDL of rats fed diets enriched with mapará and tambaqui increased - these fish contain omega- 6 and omega-3 fatty acids. The plasma glucose levels did not differ significantly from those of the control group, which was also observed by Simão et al. ${ }^{31}$ and Wilkson et al. ${ }^{32}$ while supplementing a human diet with fish oil. Mortiz et al. ${ }^{33}$ stated that rats fed with chow enriched with fish oil tended to have lower blood glucose, total cholesterol, and LDL-C and higher TG than the control group. Many works have showed that lipid metabolism is regulated by leptin, a protein hormone produced mainly by adipose tissue ${ }^{34}$. According to Nogalska et al. ${ }^{35}$ higher expression of the leptin gene partially clarifies the low lysogenic activity of the white adipose tissue of old animals. This finding corroborates our studies which showed low lipogenesis in the adipose tissues and concomitant leptin increase in the rats fed enriched chow.

In conclusion, this study found that diets enriched with fatty Amazon fish changed the lipid metabolism of rats effectively lowering plasma lipids (cholesterol, TG, and LDL) and increasing $\mathrm{HDL}$. These results suggest that regular consumption of fish with these characteristics is beneficial.

\section{ACKNOWLEDGMENTS}

The authors thank Fundação de Amparo a Pesquisa do Amazonas (Process 3008/10) and the Instituto Nacional de Pesquisa da Amazônia.

\section{CONTRIBUTORS}

FCA SOUZA is the first author; she designed, coordinated and organized all experiments. She carried out an exhaustive review of the literature. In addition, performed statistical analyses and interpretation and was responsible for writing the article. NP GARCIA participated to the experimental design, data analysis in laboratory and participated in the writing of the article. RSA SALES participated to the exhaustive laboratory analysis, particularly for the preparation of the diet and experimental procedures. JPL AGUIAR performed several laboratory analysis, interpretation and participated in the writing of the article. WLP DUNCAN participated in the statistical analysis, writing and reviewing the manuscript. RP CARVALHO is the investigator responsible for the overall study.

\section{REFERENCES}

1. Lameu EB, de Oliveira GMM, Godoy PH, Cárcano CBM, Cárcano FM. Catabolismo muscular nos pa- 
cientes com infarto agudo do miocárdio. Rev SOCERJ. 2005; 18(2):137-40.

2. Geloneze B. Síndrome metabólica: mito ou realidade? Arq Bra Endocrinol Metab. 2006; 50(3):409-11.

3. Assis MAA. Consulta de nutrição: controle e prevenção do colesterol elevado. Florianópolis: Insular; 1997.

4. Gonçalves RC, Faria KRM, Silva PI, Mattar Filho R, Malafaia G. Perfil lipídico e os fatores de risco para a doença aterosclerose em metalúrgicos de Quirinópolis-GO. Enciclopédia Biosfera. 2012; 8(14): 1618-2012.

5. Ajayi OB, Ajayi DD. Effect of oilseed diets on plasma lipid profile in albino rats. Pakistan J Nutr. 2009; 8(2):116-8.

6. Leichsenring $M$, Sütterlin $N$, Less $S$, Bäuman $K$, Anninos A, Becker K. Polyunsaturated fatty acids in erythrocyte and plasma lipids of children with severe protein-energy malnutrition. Acta Pediatr. 1995; 84(5):516-20.

7. Estadella D, Oyama LM, Damaso AR, Ribeiro EB, Oller do Nascimento CM. Effect o palatable hyperlipidic diet in lipid metabolism os sedentary and exercised rats. Nutrition. 2004; 20(2):218-24.

8. Costa RP, Menendez G, Bricarello LP, Elias MC, Ito M. Óleo de peixe, fitosteróis, soja e antioxidantes: impacto nos lípides e na aterosclerose. Rev Soc Cardiol. 2000; 10(6):819-27.

9. Connor SL, Connor WE. Are fish oils beneficial in the prevention and treatment of coronary artery disease? Am J Clin Nutr. 1997; 66(Suppl):1020S-31S.

10. Xin W, Wei W, Li XY. Short-term effects of fish-oil supplementation on heart rate variability in humans: A meta-analysis of randomized controlled trials. Am J Clin Nutr. 2013; 97(5):926-35.

11. Robinson AM, Williamson DH. Control of glucose metabolism in isolated acini of the lactating mammary gland of rat: Effects of oleate on glucose utilization and lipogenesis. Biochem J. 1978; 170(3):609-13.

12. Stanbie D, Browsey RW, Crettaz M, Denton RM. Acute effects in vivo of anti-insulin serum on rates of fatty acid synthesis and activities of acetylcoenzyme a carboxylase and pyruvate dehydrogenase in liver and epididymal adipose tissue of fed rats. Biochem J. 1976; 160(2):413-26.

13. Oller do Nascimento CM, Williamson DH. Evidence for conservation of dietary lipid in the rat during lactation and the immediate period after removal of the litter. Biochem J. 1986; 239(1):233-6.

14. Johann $G$, Lentini EA. Simultaneous determination of glycogen and lipids from heart muscle. Anal Biochem. 1979; 43(1):183-7.
15. Abadie JM, Malcom GT, Porter JR, Svec F. Can associations between free fatty acid levels and metabolic parameters determine insulin resistance development in obese Zucker rats? Life Sci. 2001; 69(22):2675-83.

16. Gurnell M, Savage DB, Chatterjee VK, O'Rahilly S. The metabolic syndrome: Peroxisome proliferatoractivated receptor gamma and its therapeutic modulation. J Clin Endocrinol Metab. 2003; 88(6): 2412-21.

17. Gaíva MH, Couto RC, Oyama,LM, Couto GE, Silveira $\mathrm{VL}$, Ribeiro EB, et al. Polyinsaturated fatty acid-rich diets: Effect on adipose tissue metabolism in rats. Br J Nutr. 2001; 86(3):371-7.

18. French S, Robinson T. Fats and food intake. Curr Opin Clin Nutr Metab Care. 2003; 6(6):629-34.

19. Beglinger $C$, Degen L. Fat in the intestine as a regulator of appetite-tole of CCK. Physiol Behav. 2004; 83(4):617-21.

20. Tso P, Liu M. Apolipoprotein A-IV, food intake, and obesity. Physiol Behav. 2004; 83(4):631-43.

21. Himaya A, Fantino M, Antoine JM, Brondel L, LouisSylvestre J. Satiety power of dietary fat: A new apprasial. Am J Clin Nutr. 1997; 65(5):1410-8.

22. Keelan M, Clandinin MT, Thompson ABR. Refeeding varyning fatty acid and cholesterol diets alters phospholipids in rat intestinal brush border membrane. Lipids. 1997; 32(8):895-905.

23. Leonhardt $M$, Langhans W. Fatty acid oxidation and control of food intake. Physiol Behav. 2004; 83(4): 645-51.

24. National Cholesterol Education Program. Detection, evaluation, and treatment of high blood cholesterol in adults (Adult Treatment Panel III). Final report. Bethesed (MD): National Heart, Lung, and Blood Institute, 2002 Sept. Report n02-5215.

25. Nieves DJ, Cnop M, Retzlaff B, Walden CE, Brunzell JD, Knopp $\mathrm{RH}$, et al. The atherogenic lipoprotein profile associated with obesity and insulin resistance is largely attributable to intra-abdominal fat. Diabetes. 2003; 52(4):172-9.

26. Suprijana O, Terpstra AHM, Van Lith HA, Van Tol A, Lemmens $A G$, Geelhoed-Mieras MM. Plasma lipids and apolipoproteins in rats fed diets with type of fat (fish oil versus corn oil) and fiber (pectin versus cellulose) as vaiables. Nutr Res. 1997; 17(7):1187-97.

27. Kim HK, Choi S, Choi H. Suppression of hepatic fatty acid synthase by feeding $\alpha$-linolenic acid rich Perilla oil lowers plasma triacylglycerol level in rats. J Nutr Biochem. 2004; 15(8):485-92.

28. Brooks SP, Lampi BJ. Effects of dietary fat on whole body fatty aci syntesis in weanling rats. J Nutr. Biochem. 1999; 10(5):291-8. 
29. Charman A, Muriithi EW, Milne E, Wheatley DJ, Armstrong RA, Belcher PR. Fish oil before cardiac surgery: Neutrophil activation is unaffected but myocardial damage is moderated. Prostaglandins Leukot Essent Fatty Acids. 2005; 72(4):257-65.

30. Singer P. Fluvastantin plus fish oil are more effective on cardiovascular risk factors than fluvastatin alone. Prostaglandins Leukot Essent Fatty Acids. 2005; 13(22):123-5.

31. Simão ANC, Godeny P, Lozovoy MAB, Dichi JB, Dich I. Efeito dos ácidos graxos n-3 no perfil glicêmico e lipídico, no estresse oxidativo e na capacidade antioxidante total de pacientes com síndrome metabólica. Arq Bra Endocrinol Metab. 2010; 54(5): 463-69.

32. Wilkinson $P$, Leach $C$, Ah-Sing EE, Hussain N, Miller GJ, Millward DJ, et al. Influence of alpha-linolenic acid and fish-oil on markers of cardiovascular risk in subjects with an atherogenic lipoprotein phenotype. Atherosclerosis. 2005; 181(1):115-24.
33. Moritz B, Wazlawik E, Minatti J, Miranda RCD. Interferência dos ácidos graxos ômega-3 nos lipídeos sangüíneos de ratos submetidos ao exercício de natação. Rev Nutr. 2008; 21(6):659-69. doi: 10.1590/S1415-52732008000600005

34. Iritani N, Sugimoto T, Fukuda H. Gene expression of leptin, insulin receptors and lipogenic enzymes are coordinately regulated by insulin and dietary fat in rats. J Nutr. 2000; 130(5):1183-8.

35. Nogalska A, Sucajtys-Szulc E, Swierczynski J. Leptin decreases lipogenic enzyme gene expression through modification of SREBP-1c gene expression in white adipose tissue of aging rats. Metabolism. 2005; 54(8):1041-7.
Received on: 21/5/2013

Final version on: 4/11/2013

Approved on: 21/12/2013 
